\title{
Relationships Between Airborne Pseudoperonospora cubensis Sporangia, Environmental Conditions, and Cucumber Downy Mildew Severity
}

L. L. Granke, former Visiting Research Associate, J. J. Morrice, former Research Assistant, and M. K. Hausbeck, Professor and Extension Specialist, Department of Plant, Soil, and Microbial Sciences, Michigan State University, East Lansing 48824

\begin{abstract}
Granke, L. L., Morrice, J. J., and Hausbeck, M. K. 2014. Relationships between airborne Pseudoperonospora cubensis sporangia, environmental conditions, and cucumber downy mildew severity. Plant Dis. 98:674-681.

Airborne Pseudoperonospora cubensis sporangia were collected $0.5 \mathrm{~m}$ above the ground from May to late September or early October 2010 and 2011 in unsprayed cucumber (Cucumis sativus) fields in Benton Harbor and Frankenmuth, MI. Cucumber downy mildew incidence and severity were evaluated weekly within each field from June until September or October. The first airborne sporangium was detected before the crop was planted for each site-year. The greatest numbers of airborne sporangia were detected when moderate to high disease severity ( $\geq 5 \%$ symptomatic leaf area) was detected within the field. Fewer airborne sporangia were present with low disease severity $(<5 \%$ symptomatic leaf area), and even fewer were detected prior to planting the

cucumber crop. The number of airborne sporangia detected, time post planting, planting number (first versus second versus third planting), temperature, and leaf wetness were positively associated and solar radiation was negatively associated with disease occurrence for at least one site-year. Michigan growers currently use an aggressive, calendarbased fungicide program to manage cucumber downy mildew. Because airborne sporangium concentrations were one of the most important factors identified in this study, the current fungicide recommendation of decreasing the spray interval following disease detection in an area is warranted.
\end{abstract}

Cucurbit downy mildew, caused by Pseudoperonospora cubensis (Berk. \& M.A. Curtis) Rostovzev, has been reported in over 70 countries worldwide $(13,23)$. P. cubensis reemerged as a major pathogen of cucurbit crops in the United States in 2004 (10), and downy mildew has been an annual problem in Michigan since 2005. Although most cucurbits are susceptible to downy mildew $(14,20)$, disease symptoms are most severe on cucumber (Cucumis sativus L.; 18). Michigan is the top producer of pickling cucumber in the United States (1), and losses attributed to downy mildew may threaten long-term viability of the cucumber industry (21).

$P$. cubensis is spread field-to-field via windborne sporangia, which may be transported long distances (up to $1,000 \mathrm{~km} ; 19$ ). Sporangial survival over long distances is limited to a maximum of 1 to 16 days (4) and is affected by temperature, relative humidity (RH; 26), and, especially, solar radiation (11). Airborne sporangium concentrations are thought to be the most important biotic factor determining disease onset (3). The number of airborne sporangia observed above a field varies based on time of day, distance from the canopy, environmental conditions, and disease severity within the field $(9,16,22)$.

In addition to viable sporangia, favorable environmental conditions are necessary for establishment and progress of an epidemic when a susceptible host is present. The effects of temperature and leaf wetness on sporangia germination and infection of cucumber by $P$. cubensis have been investigated in controlled growth-chamber studies $(3,18)$. Previous studies have found that only $2 \mathrm{~h}$ of leaf wetness are required for infection to occur on cucumber but infection is more likely to occur with longer leaf wetness periods $(3,18)$. The optimum temperature for infection has been reported as approximately 15 to $20^{\circ} \mathrm{C}(6,17)$. Older reports $(3,6)$ place the maximum temperature for infection at $25^{\circ} \mathrm{C}$ but, in a more recent study (18), infection was observed when plants were incubated at $30^{\circ} \mathrm{C}$,

Corresponding author: M. K. Hausbeck, E-mail: hausbec1@msu.edu

Accepted for publication 24 November 2013.

http://dx.doi.org/10.1094/PDIS-05-13-0567-RE

(c) 2014 The American Phytopathological Society the highest temperature tested, suggesting that current pathogen populations may be better adapted to infect at higher temperatures. When a risk threshold model was developed based on results of controlled growth-chamber studies, it was predicted that cucumber could become infected and display symptoms at 7 days post inoculation at temperatures from 5 to $30^{\circ} \mathrm{C}$ and leaf wetness periods of 1 to $5 \mathrm{~h}$ (18). In a greenhouse study, a daily mean $\mathrm{RH}$ $\geq 80 \%$, daily mean temperatures of 15 to $25^{\circ} \mathrm{C}$, and $\leq 5^{\circ} \mathrm{C}$ fluctuation in the temperatures within a day were reported as conducive for infections to occur (27). The incubation period for downy mildew ranges from 4 to 12 days depending on temperature, photoperiod, inoculum concentration, and leaf wetness duration $(3,26)$.

Currently, downy mildew of cucumber is managed using an aggressive fungicide application program, which is estimated to cost Michigan cucumber growers over \$6 million annually (M. K. Hausbeck, unpublished). Severe downy mildew epidemics may result in total crop loss. Fungicides are applied on a calendar-based schedule, where applications are advised every 7 days before disease is reported in the state and every 5 days thereafter. By better understanding the relationships between airborne sporangium concentrations, environmental conditions, and disease onset and progress, we may be able to suggest when fungicide applications may be unnecessary because of unfavorable conditions for downy mildew. The objective of this study was to examine relationships between numbers of airborne sporangia, environmental conditions, and disease severity in unsprayed pickling cucumber fields.

\section{Materials and Methods}

Collection of field data. Numbers of airborne sporangia were monitored throughout the growing season (May to September or October) in a 'Vlaspik' pickling cucumber field at the Southwest Research and Extension Center in Benton Harbor, MI (southwest, site 1) and the Saginaw Valley Bean and Beet Research Farm in Frankenmuth, MI (eastern, site 2) in 2010 and 2011. Seeds were planted $30 \mathrm{~cm}$ apart in holes in black polyethylene mulch on raised (15 cm tall), shaped beds with centers $1.5 \mathrm{~m}$ apart. The plot consisted of four $31-\mathrm{m}$ long rows (100 plants/row). Seedlings were thinned so that only one plant was present in each hole. Admire (imidacloprid, $296 \mathrm{ml}$ ) was applied through the drip-irrigation 
system once at the beginning of the season to control insect pests. Topsin (thiophanate-methyl, $240 \mathrm{ml}$ ) was applied every 7 days to control powdery mildew. To allow continuous monitoring of downy mildew throughout the growing season, multiple plots were planted in both locations for both years. In 2010 at site 1, two plots were planted and monitored: one from 27 May until 3 August and an adjacent plot from 27 July until 28 September. At site 2 in 2010, three plots were planted and monitored: one from 8 June until 9 August, an adjacent plot from 19 July until 15 September, and the original plot was replanted on 30 August and monitored until 29 September. In 2011, two adjacent plots were monitored at each site. At site 1, the first plot was monitored from 7 June to 1 August and the second plot from 1 August to 6 September. At site 2, plots were monitored from 27 June to 22 August and 29 August to 19 September.

A volumetric spore sampler (Burkard Manufacturing Co Ltd.) with a sampling airflow rate of 10 liters/min was used to monitor numbers of airborne $P$. cubensis sporangia. The sampler was placed in the center of the plot with the orifice approximately 0.5 $\mathrm{m}$ above ground height. Sporangia were impacted onto Melinex tapes (Burkard Manufacturing Co. Ltd.) coated with an adhesive mixture of petroleum jelly and paraffin $(9: 1, \mathrm{wt} / \mathrm{wt})$ dissolved in sufficient toluene (approximately $3 \mathrm{ml}$ per $50 \mathrm{~g}$ of mixture) to result in a thick consistency. Tapes were removed weekly, cut into 48-mm lengths, scored at hourly intervals, and stained with aniline blue in glycerol $(0.14 \mathrm{mg}$ of aniline blue, $20 \mathrm{ml}$ of distilled water, $15 \mathrm{ml}$ of glycerol, and $10 \mathrm{ml}$ of $85 \%$ lactic acid), mounted on glass slides under 22-by-50-mm cover slips, and sealed using Cytoseal (Richard-Allan Scientific). P. cubensis sporangia were examined at $\times 400$ magnification, identified based on morphological characteristics, and counted. Hourly environmental data-temperature $\left({ }^{\circ} \mathrm{C}\right)$, RH $(\%)$, precipitation $(\mathrm{mm})$, solar radiation $\left(\mathrm{kJ} / \mathrm{m}^{2}\right)$, and wind speed $(\mathrm{m} / \mathrm{s})$ - were recorded by a CR10 weather station (Campbell Scientific) at each site and downloaded from the Michigan State University Enviro-weather website. A second on-site weather station using a Watchdog model 450 data logger, leaf wetness sensor ( $45^{\circ}$ angle facing north), and tipping bucket rain gauge (Spectrum Technologies) was placed in each field to record leaf wetness $(0$ to-15 scale, which was converted to a binary scale where values $\geq 6$ were considered wet) and was used in 2011 to provide temperature, $\mathrm{RH}$, and rain data for site 1 when the Enviro-weather station malfunctioned ( 0200 h 29 May to 1500 h 31 May).

Disease incidence and severity were assessed weekly at each site. Individual plants were examined for presence or absence of disease symptoms and pathogen signs. Disease severity was assessed for a subset of 80 plants (20 per row) using a visual estimate of symptomatic leaf area ( 0 to $100 \%)$. For the first and third rows in the plot, the first 5 plants were rated and, after bypassing 20 plants, the next 5 plants were rated, and so forth until 20 plants were rated in each row. For the second and fourth row, the first 10 plants were bypassed, the next 5 plants were rated, the next 20 plants were bypassed, and so forth as described above.

Data analyses. All statistical analyses were performed using the SAS statistical package (version 9.3; SAS Institute, Inc.). Correlation analyses were performed using the CORR procedure in SAS to determine whether associations existed between sporangium concentrations, temperature, and RH within each hour. Hourly airborne sporangia counts were averaged across hours (from 0600 to 1400) to generate a mean number of airborne sporangia for each level of disease severity (before planting, low [0 to $<5 \%$ ], moderate [5 to $<20 \%$ ], and high [ $\geq 20 \%$ symptomatic leaf area]) observed in the field. Using PROC MIXED, these data were subjected to analysis of variance $(P \leq 0.05)$, and Fisher's least significant difference was used for separation of means. Disease incidence was used to separate the growing season into two categories: periods where infection was able to occur (infection periods) and periods when no new infections were observed. Because it takes 5 to 7 days for symptoms of downy mildew to manifest following infection, and symptoms could develop at any time in the week between ratings, environmental condition summaries (average temperature, hours of leaf wetness, longest consecutive period of leaf wetness, and total solar radiation) and the cumulative number of airborne sporangia were calculated for the period 7 days prior to the current disease rating to reflect the time period when infection occurred. Associations between infection periods and environmental conditions were measured by Spearman's rank correlation coefficient using PROC CORR. The NPAR1WAY procedure was used to conduct the Kolmogorov-Smirnov (K-S) test, a nonparametric test that investigates the hypothesis that two samples come from identical distributions (24). This test was used to determine differences in the distribution of environmental conditions during infection periods and periods where no new infections were observed in this study. Because of the relatively small sample size ( $n=$ as small as 27 ), Monte Carlo estimation was used to derive exact $P$ values for the K-S test.

To confirm the results of these univariate tests, a stepwise discriminant analysis (PROC STEPDISC) was conducted to select those variables best at discriminating between infection periods and periods where no new infections occurred for each year for both sites combined and for the pooled dataset for both sites and years. To fulfill the assumption of normality for discriminant analysis, transformations were applied to the following variables: temperature (square root), total hours of leaf wetness (square root), total solar radiation (natural $\log$ ), and total number of airborne sporangia (box-cox). Time post planting (natural log transformed) was also included as a variable in the analyses. A singularity (tolerance) of 0.1 was used to bypass multicollinearity. The significance levels for F-to-enter and F-to-stay values were set to 0.15 and 0.3 , respectively.

\section{Results}

Sporangia were first observed as soon as the day of and as long as 5 days after spore trapping initiation at both sites in 2010 and 2011 (Table 1). Fewer sporangia were caught over the course of the season at site 1 in 2010 (1,125 total sporangia) and 2011 (22,919 total sporangia) than at site 2 ( $>340,000$ total sporangia/year). The number of airborne sporangia detected varied widely throughout a single growing season (Figs. 1 and 2). At site 1 in 2010, downy mildew was not observed until August and disease incidence within this particular cucumber field was low, with only $2 \%$ (5 of 300 plants) of the first planting and $6 \%$ (13 of 224 plants) of the second planting showing symptoms (Fig. 1). In 2011, no disease was noted at site 1 for the first planting of cucumber, and spor-

Table 1. Dates of the sampling period, frequency (\%) of days with at least one Pseudoperonospora cubensis sporangium detected (trapping days), date that the first sporangium was detected (First spore), total number of sporangia sampled during the sampling period (Total spores), and the maximum daily sporangium concentration (Maximum spores) in unsprayed 'Vlaspik' pickling cucumber fields at two research farms in Michigan in 2010 and 2011

\begin{tabular}{|c|c|c|c|c|c|c|}
\hline \multirow[b]{2}{*}{ Site, year } & \multirow[b]{2}{*}{ Sampling date $(n)^{\mathbf{z}}$} & \multirow[b]{2}{*}{ Trapping days (\%) } & \multirow[b]{2}{*}{ First spore } & \multirow[b]{2}{*}{ Total spores } & \multicolumn{2}{|c|}{ Maximum spores } \\
\hline & & & & & Spores/day & Date \\
\hline \multicolumn{7}{|l|}{ Site 1} \\
\hline 2010 & 11 May to 28 September (141) & 70 & 13 May & 1,125 & 140 & 19 August \\
\hline 2011 & 18 May to 3 October (139) & 79 & 22 May & 22,919 & 2,297 & 10 September \\
\hline \multicolumn{7}{|c|}{ (2) } \\
\hline 2010 & 11 May to 5 October (148) & 84 & 11 May & 431,669 & 132,371 & 2 August \\
\hline 2011 & 18 May to 19 September (125) & 68 & 23 May & 341,154 & 51,039 & 16 August \\
\hline
\end{tabular}

${ }^{\mathrm{z}}$ Numbers in parentheses $=$ number of days. 
angium concentrations were correspondingly low during this period. For the second planting, sporangium concentrations were greater and appeared to precede or coincide with an increase in disease incidence (Fig. 1). At site 2, more airborne sporangia were detected in August, when the first crop of cucumber had a severe epidemic of downy mildew in the field, than at other times throughout the growing season (Fig. 2). The greatest daily sporangium concentration occurred at site 2, with 132,371 sporangia caught on 2 August 2010 (Table 1). A daily pattern was not observed for the number of airborne sporangia detected in each hour before the crop was planted (Fig. 3), likely due to few sporangia being trapped in this period. A distinctive $0900 \mathrm{~h}$ peak in airborne sporangium concentrations was observed when low (Fig. 3) or high (Fig. 3) disease severity was observed in the field. Although the regression models generated for low and high disease severity had a similar shape, the scale was much greater for high disease severity. For moderate disease severity (Fig. 3), the modeled daily pattern for airborne sporangia was a more gradual curve, with peak concentrations from 1100 to $1400 \mathrm{~h}$.

Generally, numbers of airborne sporangia detected in 1-h periods were not significantly correlated with $\mathrm{RH}$ recorded in the same 1-h periods for the entire day. When correlations were calculated for each hour of the day between 0600 to $1400 \mathrm{~h}, \mathrm{RH}$ was positively correlated with numbers of airborne sporangia for 0700 , 0800, 0900, and $1000 \mathrm{~h}$ for the full data set (Table 2). When grouped by disease severity (including the period of time before the cucumber crop was planted), numbers of airborne sporangia were negatively correlated with $\mathrm{RH}$ for the low ( 0 to $<5 \%$ symptomatic leaf area) and high ( $>20 \%$ symptomatic leaf area) disease categories. Before the cucumber crop was planted, RH was negatively correlated with numbers of airborne sporangia at $0900 \mathrm{~h}$. RH was also negatively correlated with numbers of airborne sporangia at 1100 and $1200 \mathrm{~h}$, when disease severity was low $(<5 \%)$, and positively correlated at $0800 \mathrm{~h}$, when disease severity was moderate $(5$ to $<20 \%$ ) (Table 2 ).

Temperature in 1-h periods was positively correlated with numbers of airborne sporangia in the same 1-h periods for the entire day and for 0700 to $1400 \mathrm{~h}$. When factors were grouped by disease severity, sporangium concentrations were significantly correlated with temperature when $\geq 5 \%$ symptomatic leaf area was observed. When $<5 \%$ of the leaf area was symptomatic or before the crop was planted, the relationship between temperature and numbers of airborne sporangia were less clear because correlation coefficients were low. At moderate disease severity, temperature was positively correlated for 0900 to $1400 \mathrm{~h}$. At high disease severity, temperature was positively correlated for 0600 to $1400 \mathrm{~h}$ (Table 3).

Wind speed in 1-h periods was negatively correlated with numbers of airborne sporangia in the same 1-h periods for the entire dataset and for 0600 to $1400 \mathrm{~h}$. Wind speed was not significantly correlated with numbers of airborne sporangia before the crop was planted. When factors were grouped by disease severity, numbers of airborne sporangia were significantly correlated with wind speed for low and moderate disease severity, although correlation coefficients were low. At low disease severity, wind speeds were negatively correlated with airborne sporangium concentrations from 0800 to 1100 and 1300 h. At moderate and high disease severity, negative correlations were also observed from 1100 to 1300 h (Table 4).

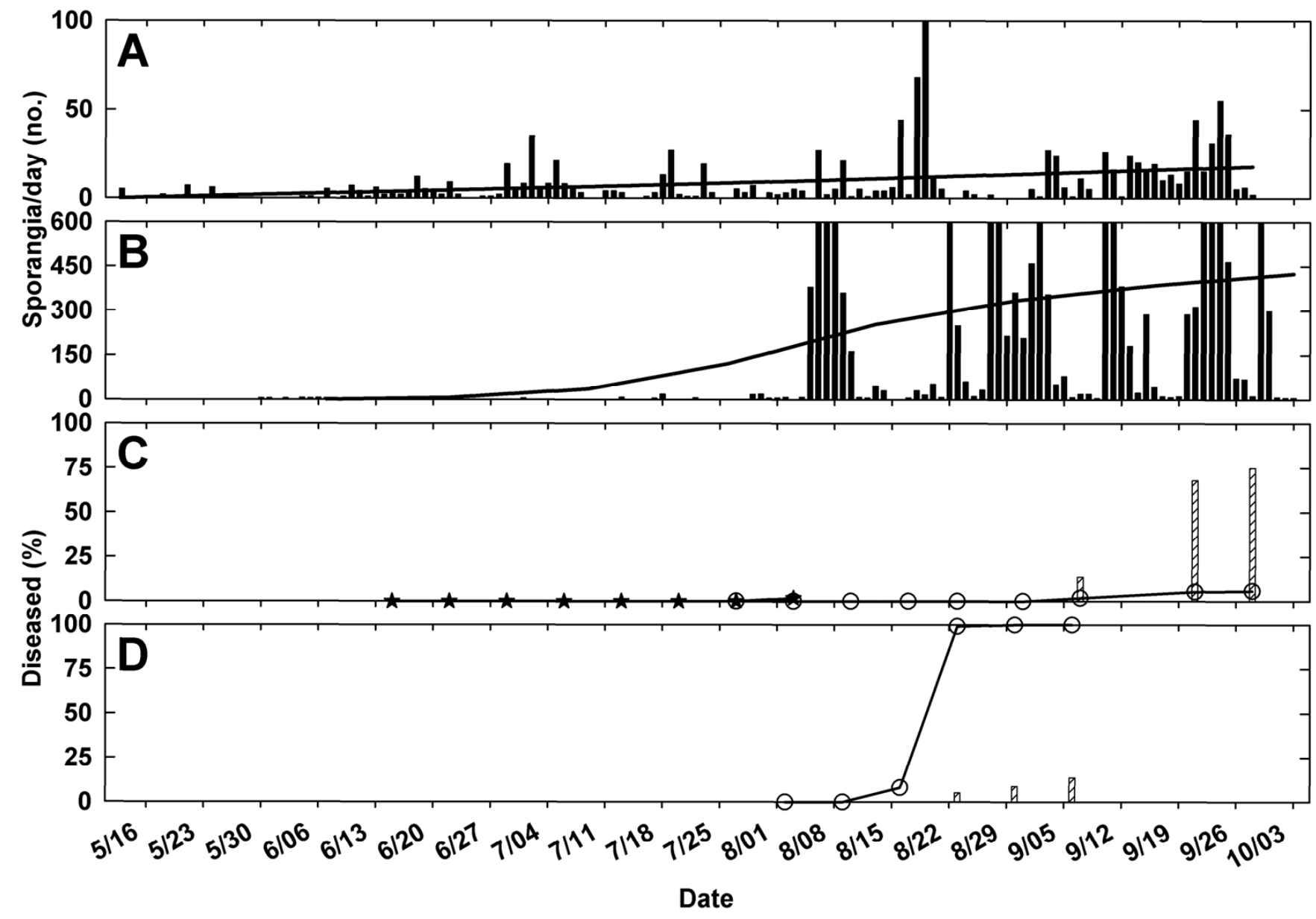

Fig. 1. Daily concentrations of Pseudoperonospora cubensis sporangia detected in an unsprayed 'Vlaspik' cucumber field at site 1 in A, 2010 and B, 2011 over the sampling season. Sporangium concentrations $A,>100$ or B, $>600$ sporangia/day were cropped from the figure. Curves (A and B) were fitted by locally weighted regression (PROC LOESS) and relate season (16 May to 3 October) to predicted sporangium concentrations (sporangia/day) to illustrate seasonal trends. Outliers were cropped from the figure but were included in LOESS analyses. Disease incidence (percent infected) during the first (stars) and second (open circles) plantings in C, 2010 and D, 2011. Disease severity (percent symptomatic leaf area) during the first (black bars) and second (striped bars), plantings in C, 2010 and D, 2011. 
When sporangium concentrations were grouped by disease severity in the field, sporangium concentrations were lowest before planting at both sites and for both years. At site 2 in 2010 and 2011, sporangium concentrations were higher when moderate to high severity was noted in the field compared with low severity and before planting. At site 1, there was no significant difference between mean numbers of airborne sporangia regardless of disease severity but more airborne sporangia were detected after planting than before planting (Table 5).

Disease was first observed at site 1 on 3 August 2010 and 16 August 2011 (Fig. 1). At site 2, disease was first observed by 12 July 2010 and 1 August 2011 (Fig. 2). Based on pooled data from both years and sites, the environmental conditions correlated with downy mildew occurrence were sporangium concentrations, time post planting, planting number, and cumulative solar radiation (Table 6). Environmental conditions that were significantly correlated with disease occurrence for the pooled data were significant by the K-S test, except for the parameter of time post planting for both years (Table 6). In 2010, sporangium concentrations, time post planting, planting number, and cumulative solar radiation were significantly correlated; these were also significant by the K$\mathrm{S}$ test. In 2011, the number of airborne sporangia and planting number were correlated with disease occurrence and significant by the K-S test (Table 6). Results from stepwise discriminant analysis using the two classes of infection periods (favorable or unfavorable) for the pooled dataset for both years resulted in selection of the number of airborne sporangia, time post planting, cumulative solar radiation, and average temperature (Table 6). When each year was examined separately, sporangium concentrations and time post planting were selected by stepwise discriminant analysis for both years. In 2010, solar radiation and the longest leaf wetness period were also selected, and average temperature and planting number were selected in 2011. The average squared canonical correlation was higher for 2011 than 2010 or the combined dataset (Table 6). Overall, airborne sporangium concentrations were significantly associated with downy mildew occurrence based on all analyses; this is supported by graphs of the data as well (Figs. 1 and 2). Several of the other environmental conditions appeared important, including solar radiation, time post planting, and planting number.

\section{Discussion}

The presence of viable sporangia, favorable environmental conditions, and susceptible host plant tissues are necessary for a cucumber downy mildew epidemic to occur. In this study, airborne $P$. cubensis sporangia were detected in mid-May, prior to cucumber being planted in the field and within 5 days of spore trapping initiation. A previous spore trapping study in commercial cucurbit fields in Michigan also found that spores were trapped within 4 days of spore sampling initiation when sampling started in June (9). Cucumber crops are usually planted in Michigan fields in early to mid-June, unless protected by a low-tunnel system. The results of Michigan spore trapping studies suggest that airborne $P$. $\mathrm{Cu}$ bensis sporangia are present in Michigan before most susceptible crops are planted in the field. These spores could have traveled via air currents from field cucumber production in the southern United States (19) or from small greenhouses in Michigan or large greenhouse operations in neighboring regions. In May 2010 and 2011,

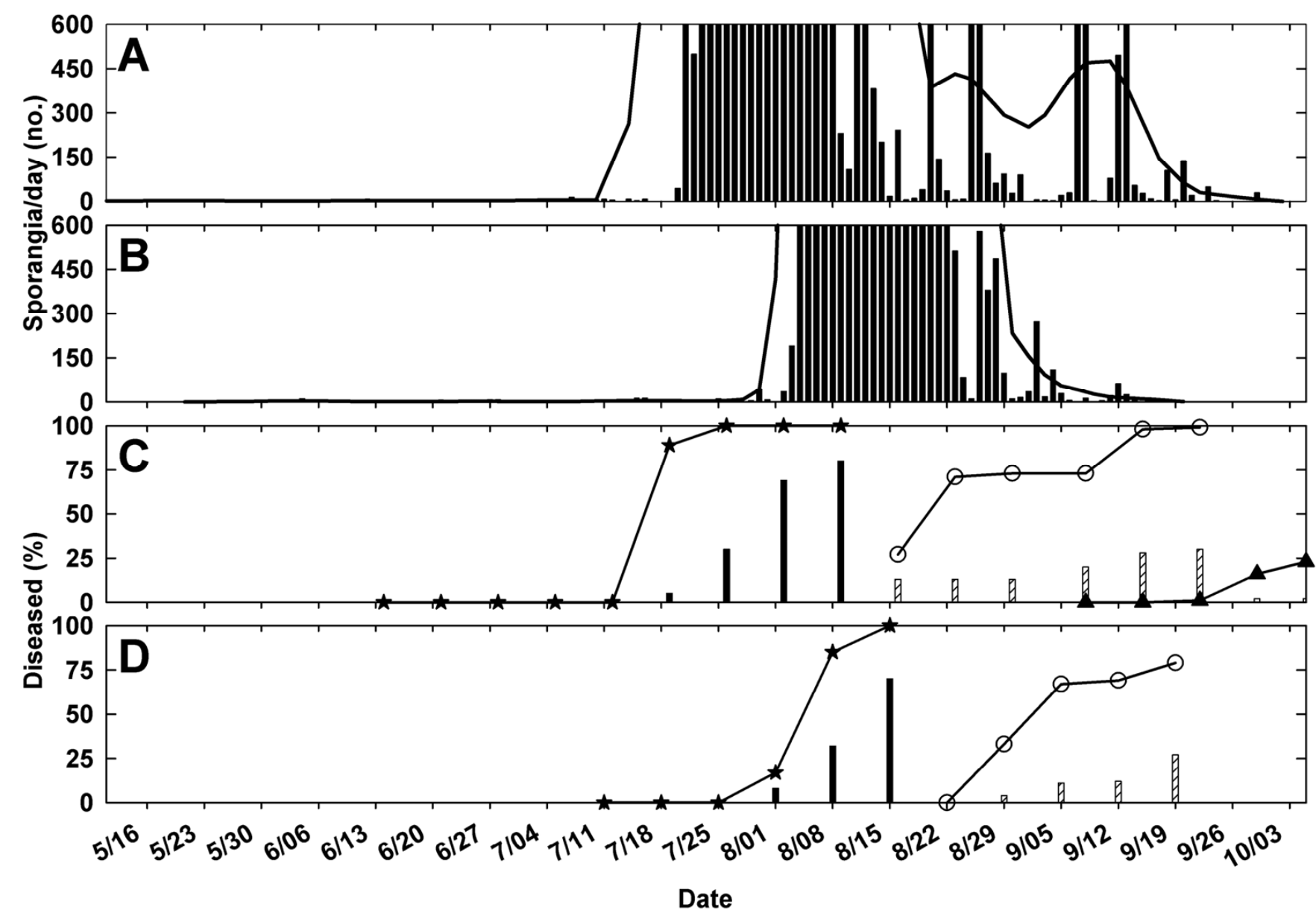

Fig. 2. Daily concentrations of Pseudoperonospora cubensis sporangia detected in an unsprayed 'Vlaspik' cucumber field at site 2 in A, 2010 and B, 2011 over the sampling season. Sporangium concentrations $>600$ sporangia/day were cropped from the figure. Curves (A and B) were fitted by locally weighted regression (PROC LOESS) and relate season (16 May to 3 October) to predicted sporangium concentrations (sporangia/day) to illustrate seasonal trends. Outliers were cropped from the figure, but were included in LOESS analyses. Disease incidence (percent infected) during the first (stars) and second (open circles) plantings in C, 2010 and D, 2011. Disease severity (percent symptomatic leaf area) during the first (black bars) and second (striped bars), plantings in C, 2010 and D, 2011. 
cucurbit downy mildew had not been reported north of the Carolinas, and no transport of spores to Michigan was anticipated according to the Cucurbit Downy Mildew ipmPIPE website. In addition, some growers in Michigan have implemented lowtunnel production of cucurbits, which allows for early planting (April); these crops may have undocumented outbreaks of downy mildew.

In the current study, it appeared that airborne sporangium concentrations were greater in fields with an active epidemic and as disease progressed. Spores were detected on 70 to $80 \%$ of days sampled in our study, which was within the range of days (42 to $100 \%$ ) during which spores were detected in the previous Michigan study in commercial, managed fields (9). Many fewer sporangia were caught at site 1 than at site 2 in our study. Little to no disease was observed for the first planting at site 1 each year, which likely contributed to the lower sporangium concentrations there. In previous years, the number of airborne sporangia detected on the east side (site 2 ) of the state was generally greater than the west side (site 1) of the state. It was hypothesized that this could be due to an influx of sporangia from large-scale production greenhouses in Ontario as well as more cucumber production on the east side of the state. Overall, seasonal sporangium concentrations were greater above unsprayed pickling cucumber fields at both site 1 and site 2 than was previously observed in commercial, managed fields in Michigan (9). The one exception to this was the Monroe County, MI trapping site in the previous study. Although the spore trap was placed in a commercial field that was managed with fungicides according to standard growing practices, that particular field was located adjacent to a large cucurbit farm that was thought to have severe downy mildew epidemics annually. Generally, a daily pattern was observed in airborne sporangium concentrations, with few sporangia caught between 1500 and $0600 \mathrm{~h}$ and peak concentrations at approximately $0900 \mathrm{~h}$, when a reduction in $\mathrm{RH}$ triggers sporangium release from the sporangiophore. Before the crop was planted, however, no daily pattern in sporangium concentrations was readily apparent, likely due to few sporangia ( $\leq 7$ in an hour) being trapped. A North Carolina study (16) reported similar results $0.5 \mathrm{~m}$ above the canopy, with no obvious daily trend at very low disease severity (approximately 1\%) and peak concentrations at approximately $0900 \mathrm{~h}$. In commercial fields in Michigan, a similar pattern was also observed (9). Spore trapping studies looking at downy mildew on watermelon in Florida (22), on cucumber in Israel (7), and cantaloupe in Texas (25) found similar results, with sporangia first being trapped at $0600 \mathrm{~h}$ in the watermelon and cucumber fields and at $1000 \mathrm{~h}$ in the cantaloupe field. In the Israeli study, peak concentrations were observed at $0800 \mathrm{~h}$ and a later peak at $1300 \mathrm{~h}$ was observed in the Texas study. Hence, early-morning scouting for downy mildew may aid in de-

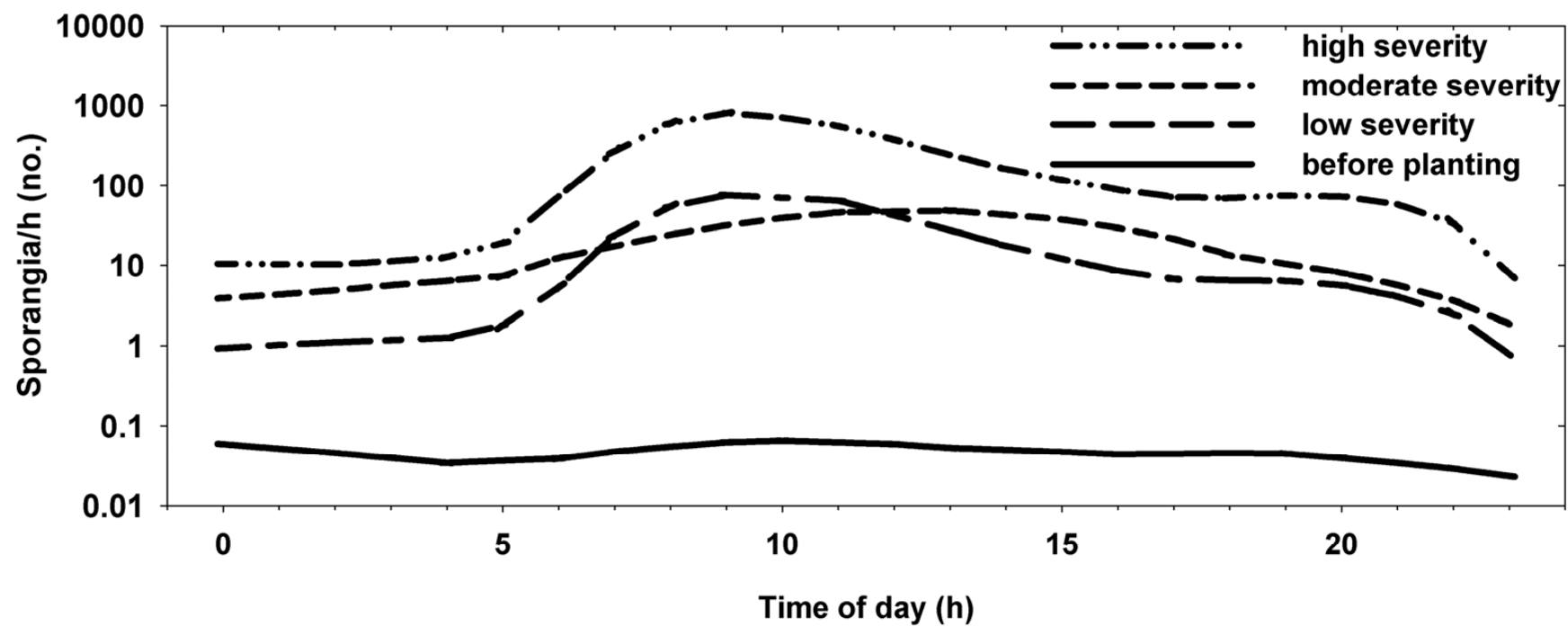

Fig. 3. Daily periodicity of Pseudoperonospora cubensis sporangia in unsprayed 'Vlaspik' cucumber fields at site 1 and site 2 in 2010 and 2011 . Data from both sites and years were pooled by disease severity: before planting, low ( $<5 \%$ foliage with visible symptoms), moderate ( 5 to $<20 \%$ foliage with visible symptoms); and high ( $>20 \%$ foliage with visible symptoms. The curve was generated using predicted values for numbers of airborne sporangia from LOESS nonparametric regression models. Models were fitted using more than 17 hourly sporangium concentrations for each site-year.

Table 2. Pearson's correlation coefficients (r) for the correlation between airborne Pseudoperonospora cubensis sporangia (spores/h) collected $0.5 \mathrm{~m}$ above the ground and average relative humidity (\%) monitored at a given average level of disease severity and hour of day in unsprayed 'Vlaspik' pickling cucumber fields at two research farms in Michigan in 2010 and 2011

\begin{tabular}{|c|c|c|c|c|c|c|c|c|c|c|}
\hline \multirow[b]{3}{*}{ Hour of day } & \multirow{2}{*}{\multicolumn{2}{|c|}{ All }} & \multirow{2}{*}{\multicolumn{2}{|c|}{ Before planting }} & \multicolumn{6}{|c|}{ Severity $^{z}$} \\
\hline & & & & & \multicolumn{2}{|c|}{ Low $(0$ to $<5 \%)$} & \multicolumn{2}{|c|}{ Moderate ( 5 to $<20 \%$ ) } & \multicolumn{2}{|c|}{ High $(>20 \%)$} \\
\hline & $\mathbf{r}$ & $P$ & $\mathbf{r}$ & $P$ & $\mathbf{r}$ & $P$ & $\mathbf{r}$ & $P$ & $\mathbf{r}$ & $P$ \\
\hline All & -0.01 & 0.5463 & -0.03 & 0.0821 & -0.03 & 0.0173 & 0.04 & 0.0618 & -0.12 & $<0.0001$ \\
\hline 0600 & 0.05 & 0.2633 & 0.05 & 0.6209 & 0.02 & 0.7747 & 0.15 & 0.2057 & -0.08 & 0.3541 \\
\hline 0700 & 0.09 & 0.0243 & -0.14 & 0.1257 & 0.11 & 0.0945 & 0.20 & 0.0971 & -0.05 & 0.5070 \\
\hline 0800 & 0.16 & $<0.0001$ & 0.01 & 0.9445 & 0.02 & 0.7537 & 0.28 & 0.0173 & 0.01 & 0.9307 \\
\hline 0900 & 0.14 & 0.0011 & -0.23 & 0.0125 & -0.04 & 0.5790 & 0.19 & 0.1086 & 0.05 & 0.5670 \\
\hline 1000 & 0.12 & 0.0061 & -0.13 & 0.1497 & -0.02 & 0.7719 & 0.23 & 0.0549 & 0.02 & 0.8405 \\
\hline 1100 & 0.03 & 0.5017 & -0.15 & 0.1034 & -0.16 & 0.0169 & 0.22 & 0.0683 & 0.04 & 0.6528 \\
\hline 1200 & 0.02 & 0.6372 & -0.09 & 0.3339 & -0.14 & 0.0282 & 0.21 & 0.0714 & 0.03 & 0.6996 \\
\hline 1300 & 0.04 & 0.3681 & 0.06 & 0.4835 & -0.08 & 0.2336 & 0.18 & 0.1424 & 0.04 & 0.5987 \\
\hline 1400 & 0.04 & 0.3504 & 0.04 & 0.6258 & -0.03 & 0.6575 & 0.19 & 0.1109 & 0.01 & 0.9227 \\
\hline
\end{tabular}

${ }^{\mathrm{z}}$ A subset of 80 plants in each field was assessed weekly using a visual estimate of symptomatic leaf area (0 to $\left.100 \%\right)$. Severity represents the mean percent symptomatic leaf area. 
tection of sporangia on the plants and improve detection when lesions are not present on the leaves.

In the current study, the number of airborne sporangia averaged for 1-h periods were positively correlated with RH in the same 1-h period from 0700 to $1000 \mathrm{~h}$ but not at 0600 or from 1100 to 1400 h. In contrast, in a North Carolina study (16), correlations between 1-h sporangium concentrations and average $\mathrm{RH}$ in the same 1-h periods were not significant. In the current study, when factors were grouped by disease severity (including the period of time before the cucumber crop was planted), sporangium concentrations were negatively correlated with $\mathrm{RH}$ for the before-planting category at $0900 \mathrm{~h}$, for the low-severity category ( 0 to $<5 \%$ symptomatic leaf area) for the average of all hours from 0600 to $1400 \mathrm{~h}$ and for 1100 and $1200 \mathrm{~h}$, and for the high-severity category
(>20\%) for the average of all hours from 0600 to $1400 \mathrm{~h}$. In the North Carolina study (16), hourly sporangium concentrations were negatively correlated with $\mathrm{RH}$ for the high-disease category ( $>20$ to $40 \%$ ) at 0900 and $1000 \mathrm{~h}$. In the previous Michigan study, a negative correlation was observed between RH and sporangium concentrations as well (9). The negative correlation between airborne sporangia and $\mathrm{RH}$ observed in these three studies supports the idea that $P$. cubensis sporangia are released following hygroscopic twisting of the sporangiophores as they dry (12).

In the current study, temperature in 1-h periods was positively correlated with the number of airborne sporangia detected in the same 1-h periods for the entire dataset combined and when separated by disease severity, except at low disease severity, when the correlation coefficient was low and the relationship was not clear.

Table 3. Pearson's correlation coefficients ( $\mathrm{r}$ ) for the correlation between airborne Pseudoperonospora cubensis sporangia (spores/h) collected $0.5 \mathrm{~m}$ above the ground and average temperature $\left({ }^{\circ} \mathrm{C}\right)$ monitored at a given level of disease severity and hour of day in unsprayed cucumber fields in two locations in Michigan in 2010 and 2011

\begin{tabular}{|c|c|c|c|c|c|c|c|c|c|c|}
\hline \multirow[b]{3}{*}{ Hour of day } & \multirow{2}{*}{\multicolumn{2}{|c|}{ All }} & \multirow{2}{*}{\multicolumn{2}{|c|}{ Before planting }} & \multicolumn{6}{|c|}{ Severity $^{\mathrm{z}}$} \\
\hline & & & & & \multicolumn{2}{|c|}{ Low $(0$ to $<5 \%)$} & \multicolumn{2}{|c|}{ Moderate $(5$ to $<20 \%)$} & \multicolumn{2}{|c|}{ High $(>20 \%)$} \\
\hline & $\mathbf{r}$ & $P$ & $\mathbf{r}$ & $P$ & $\mathbf{r}$ & $P$ & $\mathbf{r}$ & $P$ & $\mathbf{r}$ & $P$ \\
\hline All & 0.14 & $<0.0001$ & 0.07 & $<0.0001$ & -0.04 & 0.0012 & 0.27 & $<0.0001$ & 0.42 & $<0.0001$ \\
\hline 0600 & 0.08 & 0.0591 & 0.16 & 0.0806 & -0.13 & 0.0495 & -0.06 & 0.6106 & 0.29 & 0.0003 \\
\hline 0700 & 0.11 & 0.0086 & 0.09 & 0.3485 & -0.12 & 0.0589 & -0.13 & 0.2708 & 0.40 & $<0.0001$ \\
\hline 0800 & 0.14 & 0.0008 & 0.13 & 0.1492 & -0.06 & 0.3692 & 0.15 & 0.1946 & 0.52 & $<0.0001$ \\
\hline 0900 & 0.14 & 0.0010 & 0.12 & 0.1979 & -0.05 & 0.4698 & 0.29 & 0.0132 & 0.49 & $<0.0001$ \\
\hline 1000 & 0.16 & 0.0001 & 0.17 & 0.0734 & -0.04 & 0.5535 & 0.39 & 0.0008 & 0.49 & $<0.0001$ \\
\hline 1100 & 0.19 & $<0.0001$ & 0.08 & 0.3748 & 0.06 & 0.3491 & 0.46 & $<0.0001$ & 0.50 & $<0.0001$ \\
\hline 1200 & 0.17 & $<0.0001$ & 0.09 & 0.3433 & -0.04 & 0.5780 & 0.36 & 0.0019 & 0.49 & $<0.0001$ \\
\hline 1300 & 0.16 & 0.0001 & -0.13 & 0.1599 & 0.06 & 0.3609 & 0.30 & 0.0100 & 0.43 & $<0.0001$ \\
\hline 1400 & 0.17 & $<0.0001$ & 0.06 & 0.5393 & 0.03 & 0.6942 & 0.28 & 0.0156 & 0.45 & $<0.0001$ \\
\hline
\end{tabular}

${ }^{\mathrm{z}}$ A subset of 80 plants in each field was assessed weekly using a visual estimate of symptomatic leaf area (0 to $\left.100 \%\right)$. Severity represents the mean percent symptomatic leaf area.

Table 4. Pearson's correlation coefficients ( $\mathrm{r}$ ) for the correlation between airborne Pseudoperonospora cubensis sporangia (spores/h) collected $0.5 \mathrm{~m}$ above the ground and average wind speed $(\mathrm{m} / \mathrm{s})$ monitored at a given level of disease severity and hour of day in unsprayed 'Vlaspik' pickling cucumber fields at two research farms in Michigan in 2010 and 2011

\begin{tabular}{|c|c|c|c|c|c|c|c|c|c|c|}
\hline \multirow[b]{3}{*}{ Hour of day } & \multirow{2}{*}{\multicolumn{2}{|c|}{ All }} & \multirow{2}{*}{\multicolumn{2}{|c|}{ Before planting }} & \multicolumn{6}{|c|}{ Severity $^{\mathrm{z}}$} \\
\hline & & & & & \multicolumn{2}{|c|}{ Low $(0$ to $<5 \%)$} & \multicolumn{2}{|c|}{ Moderate $(5$ to $<20 \%)$} & \multicolumn{2}{|c|}{ High $(>20 \%)$} \\
\hline & $\mathbf{r}$ & $P$ & $\mathbf{r}$ & $\mathbf{P}$ & $\mathbf{r}$ & $P$ & $\mathbf{r}$ & $P$ & $\mathbf{r}$ & $P$ \\
\hline All & -0.05 & $<0.0001$ & -0.03 & 0.1119 & -0.08 & $<0.0001$ & -0.05 & 0.0236 & -0.00 & 0.8166 \\
\hline 0600 & -0.15 & 0.0005 & -0.01 & 0.9210 & -0.11 & 0.0905 & -0.16 & 0.1662 & -0.19 & 0.0218 \\
\hline 0700 & -0.15 & 0.0004 & -0.10 & 0.3014 & -0.13 & 0.0487 & -0.13 & 0.2788 & -0.11 & 0.1620 \\
\hline 0800 & -0.15 & 0.0004 & -0.04 & 0.6602 & -0.19 & 0.0038 & -0.20 & 0.0928 & -0.06 & 0.4709 \\
\hline 0900 & -0.14 & 0.0012 & -0.01 & 0.8968 & -0.22 & 0.0006 & -0.18 & 0.1319 & -0.08 & 0.3397 \\
\hline 1000 & -0.14 & 0.0012 & -0.16 & 0.0879 & -0.21 & 0.0014 & -0.22 & 0.0619 & -0.13 & 0.1031 \\
\hline 1100 & -0.14 & 0.0011 & -0.12 & 0.1879 & -0.16 & 0.0132 & -0.38 & 0.0010 & -0.19 & 0.0238 \\
\hline 1200 & -0.13 & 0.0026 & -0.11 & 0.2427 & -0.11 & 0.0838 & -0.28 & 0.0168 & -0.16 & 0.0507 \\
\hline 1300 & -0.15 & 0.0004 & -0.10 & 0.2607 & -0.17 & 0.0104 & -0.28 & 0.0187 & -0.17 & 0.0448 \\
\hline 1400 & -0.09 & 0.0284 & -0.08 & 0.3939 & -0.06 & 0.3646 & -0.08 & 0.4989 & -0.16 & 0.0501 \\
\hline
\end{tabular}

${ }^{\mathrm{z}}$ A subset of 80 plants in each field was assessed weekly using a visual estimate of symptomatic leaf area (0 to $\left.100 \%\right)$. Severity represents the mean percent symptomatic leaf area.

Table 5. Concentration of Pseudoperonospora cubensis sporangia $0.5 \mathrm{~m}$ above the ground in unsprayed 'Vlaspik' pickling cucumber fields at two research farms in Michigan in 2010 and 2011

\begin{tabular}{lcccc}
\hline & \multicolumn{4}{c}{ Sporangia $\mathbf{~ m}^{\mathbf{3}}$ of air $(\mathbf{m e a n} \pm$ standard error) } \\
\cline { 2 - 5 } Site, year & Before planting & Low $(\mathbf{0}$ to $<\mathbf{5 \%})$ & Moderate $(\mathbf{5}$ to $<\mathbf{2 0 \%})$ & High $(>\mathbf{2 0 \%}$ to $\mathbf{1 0 0 \%})$ \\
\hline Site 1 & $0.1 \pm 0.2 \mathrm{c}$ & & & \\
2010 & $0.1 \pm 0.0 \mathrm{~b}$ & $0.6 \pm 0.1 \mathrm{~b}$ & $1.0 \pm 0.2 \mathrm{ab}$ & $1.3 \pm 0.2 \mathrm{ab}$ \\
2011 & & & $25.3 \pm 3.7 \mathrm{a}$ & $20.9 \pm 3.7 \mathrm{a}$ \\
Site 2 & $0.1 \pm 0.0 \mathrm{c}$ & $0.2 \pm 0.0 \mathrm{c}$ & $88.5 \pm 14.1 \mathrm{~b}$ & $638.6 \pm 109.7 \mathrm{a}$ \\
2010 & $0.1 \pm 0.2 \mathrm{c}$ & $62.0 \pm 19.1 \mathrm{~b}$ & $491.9 \pm 89.9 \mathrm{a}$ & $747.6 \pm 135.7 \mathrm{a}$ \\
2011 & & & & \\
\hline
\end{tabular}

${ }^{\mathrm{z}}$ Sporangium concentrations are means of sporangia $\mathrm{m}^{-3}$ of air sampled throughout the growing season for each level of disease severity (Low, Moderate, and High). At least $155 \mathrm{~h}$ (up to 2,016 h) were used to calculate each mean and standard error. Means that share a letter within a row are not significantly different $(P<0.05)$. For severity, a subset of 80 plants in each field were assessed weekly using a visual estimate of symptomatic leaf area $(0$ to $100 \%)$. Severity represents the mean percentage symptomatic leaf area. 
Hourly correlations also indicated a positive relationship between temperature and the number of airborne sporangia detected. These results contrast those reported from the North Carolina study (16) but are in agreement with the results from the previous Michigan study (9). The North Carolina study took place for a shorter duration (16 to 29 August for Clayton and 12 August to 1 September for Clinton) and had less variation in temperature $\left(15\right.$ to $\left.42^{\circ} \mathrm{C}\right)$ than our current $\left(-1.3\right.$ to $\left.36.6^{\circ} \mathrm{C}\right)$ and past $\left(0\right.$ to $\left.36.6^{\circ} \mathrm{C}\right)$ studies in Michigan, which may explain differences in results.

Numbers of airborne sporangia detected were significantly affected by the level of disease severity within the field, with fewer sporangia detected before planting in our study. In the North Carolina study, an increase in sporangium concentrations was noted with an increasing level of disease severity until approximately 16 to $18 \%$ disease severity, then decreasing thereafter (16). At site 2 in our study, we did not note a decrease in the number of airborne sporangia detected with high $(>20 \%)$ disease severity in contrast to the results from the North Carolina study. At site 1, no significant difference was noted in mean sporangium concentrations regardless of disease severity, although trends were similar to those observed at site 2 . In the study by Neufeld et al. (16), more spores were trapped $0.5 \mathrm{~m}$ above the canopy than at 1.5 and $2 \mathrm{~m}$ above the canopy. Our spore trap orifice was closer to the canopy $(0.5 \mathrm{~m}$ above the ground), which may explain differences in results. In addition, Neufeld et al. (16) rated only the six, seventh, and eighth leaf of each plant. In our study, we estimated disease over all the leaves. Hence, even though we used the same measure of disease (percent symptomatic leaf area), our ratings do not directly correspond with the ratings by Neufeld et al (16).

Identifying the most important risk factors for disease occurrence is a good first step toward developing a disease management strategy (15). In our study, airborne sporangium concentrations were consistently positively associated with the occurrence of disease (visual symptoms). Cohen and Rotem (8) found that proximity to the inoculum source was more important than temperature for disease development in cucumber (8), which further supports the hypothesis that sporangium concentrations are a key factor influencing the development of cucumber downy mildew. The planting number (first planting versus second planting versus third planting) was positively associated with disease occurrence in correlation analyses and using discriminant analysis (2011 only). Time post planting was also consistently identified as positively associated with disease occurrence, except for the correlation analysis for 2011. Because cucumber plants are susceptible even at the cotyledon stage (5), it seems likely that higher sporangium concentrations later in the growing season were responsible for these associations.

For infection to occur, a sufficient number of viable sporangia need to be present. It has been suggested that solar radiation is the key limiting factor for $P$. cubensis sporangial survival and that temperature and RH are less important for sporangia viability (11). Solar radiation was negatively associated with disease occurrence for the 2010 and combined datasets but was not significantly associated with disease occurrence in 2011. Interestingly, cumulative solar radiation on a cloudy day affected sporangial viability less than the same dose of solar radiation on a sunny day in a previous study (11). In our current study, we were only able to measure cumulative solar radiation without regard for whether or not it was cloudy at the time.

Several previous studies have examined the effects of temperature and leaf wetness on infection and disease progress of cucurbit downy mildew. The optimum temperature for infection has been reported as approximately 15 to $20^{\circ} \mathrm{C}(6,18)$. Neufeld and Ojiambo (18) predicted that cucumber foliage could become infected and show light disease symptoms at 7 days post inoculation at temperatures from 5 to $30^{\circ} \mathrm{C}$ and leaf wetness periods of 1 to $5 \mathrm{~h}$. Leaf wetness is known to be a key factor for infection to occur based on previous studies $(3,8)$, and longer periods of leaf wetness have been shown to allow more infection to occur, even under unfavorable combinations of temperature and inoculum concentration (3). In contrast, Arauz et al. found that temperature was the main determinant of the infection extent and progress, rather than leaf wetness (2).

Table 6. Spearman's correlation $(S)$ and significance of the Kolmogorov-Smirnov (K-S) test to determine associations between weather variables and occurrence of downy mildew for 2010 and $2011^{x}$

\begin{tabular}{|c|c|c|c|c|c|c|}
\hline \multirow[b]{2}{*}{ Year, environmental conditions } & \multicolumn{3}{|c|}{ Spearman's correlation ${ }^{y}$} & \multicolumn{3}{|c|}{ Stepwise discriminant analysis ${ }^{\mathrm{z}}$} \\
\hline & $S$ & $P$ value & K-S & $P>F$ & ASCC & $P>\mathrm{ASCC}$ \\
\hline \multicolumn{7}{|l|}{2010} \\
\hline Sporangium concentration & 0.55 & 0.0007 & 0.0031 & 0.0003 & 0.3369 & 0.0003 \\
\hline Time post planting & 0.50 & 0.0027 & 0.0185 & 0.0040 & 0.6076 & $<0.0001$ \\
\hline Planting number & 0.38 & 0.0260 & 0.0366 & NS & NS & NS \\
\hline Weekly average temperature & -0.11 & 0.5520 & 0.7923 & NS & NS & NS \\
\hline Leaf wetness period & -0.05 & 0.7967 & 0.8282 & 0.0629 & 0.6524 & $<0.0001$ \\
\hline Weekly total rainfall & -0.16 & 0.3752 & 0.5505 & NS & NS & NS \\
\hline Sum of solar radiation & -0.46 & 0.0067 & 0.0018 & 0.0063 & 0.4808 & $<0.0001$ \\
\hline \multicolumn{7}{|l|}{2011} \\
\hline Sporangium concentration & 0.82 & $<0.0001$ & 0.0000 & $<0.0001$ & 0.8322 & $<0.0001$ \\
\hline Time post planting & 0.17 & 0.3867 & 0.7782 & 0.0137 & 0.7587 & $<0.0001$ \\
\hline Planting number & 0.63 & 0.0004 & 0.0027 & 0.0226 & 0.6971 & $<0.0001$ \\
\hline Weekly average temperature & -0.34 & 0.0785 & 0.0507 & 0.0275 & 0.7864 & $<0.0001$ \\
\hline Leaf wetness period & 0.23 & 0.2566 & 0.2687 & NS & NS & NS \\
\hline Weekly total rainfall & 0.09 & 0.6693 & 0.7298 & NS & NS & NS \\
\hline Sum of solar radiation & 0.05 & 0.8127 & 0.3773 & NS & NS & NS \\
\hline \multicolumn{7}{|l|}{ Both } \\
\hline Sporangium concentration & 0.70 & $<0.0001$ & $<0.0001$ & $<0.0001$ & 0.4861 & $<0.0001$ \\
\hline Time post planting & 0.35 & 0.0062 & 0.0577 & 0.0050 & 0.6037 & $<0.0001$ \\
\hline Planting number & 0.47 & 0.0001 & 0.0002 & NS & NS & NS \\
\hline Weekly average temperature & -0.21 & 0.1108 & 0.4285 & 0.0770 & 0.6254 & $<0.0001$ \\
\hline Leaf wetness period & 0.12 & 0.3541 & 0.3868 & NS & NS & NS \\
\hline Weekly total rainfall & -0.07 & 0.6103 & 0.9356 & NS & NS & NS \\
\hline Sum of solar radiation & -0.32 & 0.0123 & 0.0429 & 0.0086 & 0.5443 & $<0.0001$ \\
\hline
\end{tabular}

${ }^{\mathrm{x}}$ Environmental variables selected by stepwise discriminant analysis for differentiating between periods of time that are favorable or unfavorable for infection of cucumber by Pseudoperonospora cubensis. Data are from unsprayed 'Vlaspik' pickling cucumber fields at two research farms in Michigan. NS $=$ not selected.

${ }^{y}$ K-S test that environmental conditions in periods without and with infection belong to the same distribution. Monte Carlo estimation was used to derive exact $P$ values.

${ }^{\mathrm{z}} \mathrm{ASCC}=$ average squared canonical correlation. 
Cucumber growers in Michigan use an aggressive, calendarbased fungicide program to manage losses associated with downy mildew. In this study, we determined the key factors associated with downy mildew occurrence on cucumber as a step toward improving the current disease management strategy. Airborne sporangium concentrations, time post planting, planting number (first versus second versus third planting), temperature, and leaf wetness were positively associated with disease occurrence and solar radiation was negatively associated with disease occurrence in this study for at least one site-year. Future studies could explore whether or not fungicide applications may be reduced or avoided during periods with low leaf wetness and high solar radiation, when airborne sporangium concentrations are low. Airborne sporangium concentrations were one of the most important factors identified in this study and downy mildew severity increased as sporangium concentrations increased. Thus, the current recommendation of decreasing the fungicide spray interval following disease detection in nearby fields is warranted.

\section{Acknowledgments}

This study was supported by funding from NCR-IPM under Award Number 2003-51120-02111 S4256, Project Green under Award Number GR007-077 and GR06-099D, and the Pickle and Pepper Research Committee of Michigan State University, Pickle Packers International, Inc. We thank M. VanOverbeke, G. Carnago, B. Cortright, and K. VanderMaas for technical assistance.

\section{Literature Cited}

1. Anonymous. 2012. Vegetables Annual Summary, 01.26.2012. U.S. Dep. Agric. Natl. Agric. Stat. Serv. Online publication.

2. Arauz, L. F., Neufeld, K., Lloyd, A. L., and Ojiambo, P. S. 2010. Quantitative models for germination and infection of Pseudoperonospora cubensis in response to temperature and duration of leaf wetness. Phytopathology 100:959-967.

3. Cohen, Y. 1977. The combined effects of temperature, leaf wetness, and inoculum concentration on infection of cucumbers with Pseudoperonospora cubensis. Can. J. Bot. 55:1478-1487.

4. Cohen, Y. 1981. Downy mildew of cucurbits. Pages 341-354 in: The Downy Mildews. D. M. Spencer, ed. Academic Press, London.

5. Cohen, Y., and Eyal, H. 1977. Growth and differentiation of sporangia and sporangiophores of Pseudoperonospora cubensis on cucumber cotyledons under various combinations of light and temperature. Physiol. Plant Pathol. 10:93-103.

6. Cohen, Y., and Rotem, J. 1969. The effects of lesion development, air temperature, and duration of moist period on sporulation of Pseudoperonospora cubensis in cucumbers. Israel J. Bot. 18:135-140.

7. Cohen, Y., and Rotem, J. 1971. Dispersal and viability of sporangia of Pseudoperonospora cubensis. Trans. Br. Mycol. Soc. 57:67-74.
8. Cohen, Y., and Rotem, J. 1971. Field and growth chamber approach to epidemiology of Pseudoperonospora cubensis on cucumbers. Phytopathology 61:736-737.

9. Granke, L. L., and Hausbeck, M. K. 2011. Aerobiology of Pseudoperonospora cubensis sporangia in commercial cucurbit fields. Plant Dis. 95:1392-1400.

10. Holmes, G. J., and Thomas, C. E. 2006. The history and re-emergence of cucurbit downy mildew (Abstr.). Phytopathology 99:S171.

11. Kanetis, L., Holmes, G. J., and Ojiambo, P. S. 2009. Survival of Pseudoperonospora cubensis sporangia exposed to solar radiation. Plant Pathol. 59:313-323.

12. Lange, L., Eden, U., and Olson, L. W. 1989. Zoosporogenesis in Pseudoperonospora cubensis, the causal agent of cucurbit downy mildew. Nord. J. Bot. 8:497-504.

13. Lebeda, A., and Cohen, Y. 2011. Cucurbit downy mildew (Pseudoperonospora cubensis) - biology, ecology, epidemiology, host-pathogen interaction and control. Eur. J. Plant Pathol. 129:157-192.

14. Lebeda, A., and Urban, J. 2007. Temporal changes in pathogenicity and fungicide resistance in Pseudoperonospora cubensis populations. Acta Hortic. 731:327-336.

15. Madden, L. V., Hughes, G., and van den Bosch, F. 2007. The Study of Plant Disease Epidemics. American Phytopathological Society, St. Paul, MN.

16. Neufeld, K. N., Isard, S. A., and Ojiambo, P. S. 2013. Relationship between disease severity and escape of Pseudoperonospora cubensis sporangia from a cucumber canopy during downy mildew epidemics. Plant Pathol. 62:1366-1377.

17. Neufeld, K., and Ojiambo, P. 2010. Effects of temperature and wetness duration on sporangia germination and infection of cucurbit varieties by Pseudoperonospora cubensis. (Abstr.) Phytopathology 100:S89.

18. Neufeld, K. N., and Ojiambo, P. S. 2012. Interactive effects of temperature and leaf wetness duration on sporangia germination and infection of cucurbit hosts by Pseudoperonospora cubensis. Plant Dis. 96:345-353.

19. Ojiambo, P., and Holmes, G. 2011. Spatio-temporal spread of cucurbit downy mildew in the Eastern United States. Phytopathology 101:451-461.

20. Palti, J., and Cohen, Y. 1980. Downy mildew of cucurbits (Pseudoperonospora cubensis): The fungus and its hosts, distribution, epidemiology, and control. Phytoparasitica 8:109-147.

21. Savory, E. A., Granke, L. L., Quesada-Ocampo, L. M., Varbanova, M. Hausbeck, M. K., and Day, B. 2011. The cucurbit downy mildew pathogen Pseudoperonospora cubensis. Mol. Plant Pathol. 12:217-226.

22. Schenck, N. C. 1968. Incidence of airborne fungus spores over watermelon fields in Florida. Phytopathology 58:91-94.

23. Spencer, D. M. 1981. The Downy Mildews. Academic Press Inc., London.

24. Steel, R. G. D., and Torrie, J. H. 1980. Principles and Procedures of Statistics. A Biometrical Approach. McGraw-Hill, New York.

25. Thomas, C. E. 1977. Influence of dew on downy mildew of cantaloupes in South Texas. Phytopathology 67:1368-1369.

26. Thomas, C. E. 1996. Downy mildew. Pages 25-27 in: Compendium of Cucurbit Diseases. T. A. Zitter, ed. Cornell University Press, Ithaca, NY

27. Yang, X., Li, M., Zhao, C., Zhang, Z., and Hou, Y. 2007. Early warning model for cucumber downy mildew in unheated greenhouses. N.Z. J. Agric Res. 50:1261-1268. 